\title{
Haploinsufficiency of Human APOE Reduces Amyloid Deposition in a Mouse Model of Amyloid- $\beta$ Amyloidosis
}

\author{
Jungsu Kim, Hong Jiang, Seonha Park, Adam E. M. Eltorai, Floy R. Stewart, Hyejin Yoon, Jacob M. Basak, \\ Mary Beth Finn, and David M. Holtzman \\ Department of Neurology, Developmental Biology, Hope Center for Neurological Disorders, Knight Alzheimer's Disease Research Center, Washington \\ University School of Medicine, St. Louis, Missouri 63110
}

The $\varepsilon 4$ allele of the apolipoprotein $\mathrm{E}(A P O E)$ gene is the strongest genetic risk factor for Alzheimer's disease (AD). Evidence suggests that the effect of apoE isoforms on amyloid- $\beta(\mathrm{A} \beta)$ accumulation in the brain plays a critical role in $\mathrm{AD}$ pathogenesis. Like in humans, apoE4 expression in animal models that develop $\mathrm{A} \beta$ amyloidosis results in greater $\mathrm{A} \beta$ and amyloid deposition than with apoE3 expression. However, whether decreasing levels of apoE3 or apoE4 would promote or attenuate $\mathrm{A} \beta$-related pathology has not been directly addressed. To determine the effect of decreasing human apoE levels on $\mathrm{A} \beta$ accumulation in vivo, we generated human $A P O E$ isoform haploinsufficient mouse models by crossing APPPS1-21 mice with APOE isoform knock-in mice. By genetically manipulating APOE gene dosage, we demonstrate that decreasing human apoE levels, regardless of isoform status, results in significantly decreased amyloid plaque deposition and microglial activation. These differences in amyloid load between apoE3- and apoE4-expressing mice were not due to apoE4 protein being present at lower levels than apoE3. These data suggest that current therapeutic strategies to increase apoE levels without altering its lipidation state may actually worsen $\mathrm{A} \beta$ amyloidosis, while increasing apoE degradation or inhibiting its synthesis may be a more effective treatment approach.

\section{Introduction}

Aggregation and accumulation of amyloid $\beta(\mathrm{A} \beta)$ in the brain is a key initiating factor in the pathogenesis of Alzheimer's disease (AD) (Holtzman et al., 2011). Familial AD-causing mutations in amyloid $\beta$ precursor protein $(A P P)$, presenilin 1 (PS1), and PS2 genes have provided strong support for the crucial role of $A \beta$ aggregation in AD pathogenesis (Holtzman et al., 2011). The strongest genetic risk factor for the most common form of lateonset $\mathrm{AD}$ is the $\varepsilon 4$ allele of the apolipoprotein $\mathrm{E}(A P O E)$ gene (Strittmatter et al., 1993). Although several mechanisms for the effect of apoE4 on $\mathrm{AD}$ pathogenesis have been proposed, the primary pathway appears to be the differential effects of apoE3 and apoE4 isoforms on $\mathrm{A} \beta$ aggregation and clearance (Kim et al., 2009a; Castellano et al., 2011).

In addition to isoform status, it appears that the amount of apoE also plays a role in determining the extent of $A \beta$ accumulation in the brain. There has been intense debate as to whether potential $\mathrm{AD}$ therapeutics should increase or decrease apoE levels

Received July 24, 2011; revised 0ct. 17, 2011; accepted 0ct. 28, 2011.

Author contributions: J.K. and D.M.H. designed research; J.K., H.J., S.P., A.E.M.E., F.R.S., H.Y., J.M.B., M.B.F., and D.M.H. performed research; H.J. and D.M.H. contributed unpublished reagents/analytic tools; J.K., H.Y., J.M.B., M.B.F., and D.M.H. analyzed data; J.K., J.M.B., and D.M.H. wrote the paper.

This work was supported by NIH Grants AG13956 (D.M.H.) and P30NS069329 (J.K.), American Health Assistance Foundation grants (J.K., D.M.H.), NIH Neuroscience Blueprint Center Core Grant P30NS057105, and the Alafi Neuroimaging Laboratory Human. APOE knock-in and APPPS1-23 mice breeding pairs were gifts from Dr. Patrick Sullivan (Duke University, Durham, NC) and Dr. Mathias Jucker (University of Tübingen, Tübingen, Germany), respectively.

Correspondence should be addressed to Dr. David M. Holtzman, Washington University School of Medicine, Department of Neurology, 660 S. Euclid Avenue, Campus Box 8111, St. Louis, M0 63110. E-mail: holtzman@neuro.wustl.edu.

DOI:10.1523/JNEUROSCI.3773-11.2011

Copyright $\odot 2011$ the authors $\quad 0270-6474 / 11 / 3118007-06 \$ 15.00 / 0$
(Ashford, 2002; Rebeck et al., 2002; Teter et al., 2002; Osherovich, 2009). Initial studies clearly indicated that the deletion of the endogenous murine $A P O E$ gene causes a dramatic decrease in fibrillar and total $\mathrm{A} \beta$ deposition in $A P P$ transgenic mouse models (Bales et al., 1997). However, whether decreasing human apoE levels will have the same beneficial effect or not has not yet been answered. Some recent studies indirectly suggest that increasing, rather than decreasing, human apoE levels may be a good therapeutic approach. Therefore, understanding how modulation of human apoE levels will alter $\mathrm{AD}$ pathology must be addressed before the development of apoE-targeting drugs.

To directly test the effect of human APOE gene dosage on amyloid pathology, we generated $\mathrm{A} \beta$-depositing mouse models homozygous or hemizygous for the APOE3 or APOE4 gene. APPPS1-21 mice with two copies of APOE (APOE $3 / 3$ or $A P O E 4 / 4)$ or one copy of APOE (APOE3/- or APOE4/-) were generated by breeding APPPS1-21 mice with human $A P O E$ knock-in mice. Compared with the respective homozygous mice, APOE3/- and APOE4/- hemizygous mice had significantly decreased $\mathrm{A} \beta$ accumulation, amyloid deposition, and microgliosis. Our results strongly suggest that the reduction of human apoE levels, regardless of the isoform present, will decrease $\mathrm{A} \beta$-related $\mathrm{AD}$ pathology.

\section{Materials and Methods}

Generation of human APOE isoform mice with APPswe/PS1(L166P) mutant transgenes. To determine the gene dosage effect of human APOE3 and APOE4 on amyloid deposition, we used knock-in mouse models in which the endogenous murine Apoe gene is replaced with the APOE3 or APOE4 gene. Breeding pairs were gifts from Dr. Patrick Sullivan, Duke University, Durham, NC (Sullivan et al., 1997). APPPS1-21 mice over- 
express a human $A P P$ with a Swedish mutation (KM670/671NL) and mutant PS1 with the L166P mutation. Breeding pairs were obtained from Dr. Mathias Jucker, University of Tübingen, Tübingen, Germany (Radde et al., 2006). To replace the murine Apoe gene with human $A P O E$ isoforms, APPPS1-21 mice were bred with either $A P O E 3 / 3$ or $A P O E 4 / 4$ knock-in mice. APPPS121/APOE3/Apoe mice and APOE3/Apoe mice from the first generation were bred with each other to generate APPPS1-21/APOE3/3 and APOE3/3 mice. APPPS1-21/APOE $3 / 3$ and $A P O E 3 / 3$ mice were then bred to generate more APPPS1-21/ $A P O E 3 / 3$ mice. After successful generation of APPPS1-21/APOE3/3 mice at the third generation, APPPS1-21/APOE3/3 mice were bred with Apoe knock-out mice (Jackson Laboratory). APPPS1-21/APOE3/- mice from the fourth generation were bred with $A P O E 3 / 3$ mice to generate APPPS1-21/APOE3/3 and APPPS1-21/ $A P O E 3 /-$ mice. Littermates generated at the fifth generation were used in our analyses. Similarly, APPPS1-21/APOE4/4 and APPPS1-21/ $A P O E 4 /-$ mice were generated by using the same mating strategy. All mice used in this study were maintained on a C57BL/6J background.

Quantitative real-time PCR. mRNAs were extracted from frozen cortical tissue using Trizol and reverse transcribed with High Capacity cDNA Reverse Transcription kit (Applied Biosystems). Quantitative real-time PCR (qPCR) was performed in ABI 7500 using the default thermal cycling condition with Power SYBR (Applied Biosystems) with the following primers: forward primer, TTGCTGGTCACATTCCTGG; and reverse primer, AGGTAATCCCAAAAGCGACC. Mouse GAPDH endogenous control was used as a normalization reference. Relative mRNA levels were calculated by comparative Ct method. To confirm the specificity of qPCR reactions, dissociation curves were analyzed at the end of the $\mathrm{qPCR}$ assay.

Western blots. Cortical tissues were gently lysed in PBS and modified RIPA (1\% NP-40, 1\% sodium deoxycholate, $25 \mathrm{~mm}$ Tris- $\mathrm{HCl}, 150 \mathrm{~mm} \mathrm{NaCl}$ ) in the presence of $1 \times$ protease inhibitor mixture (Roche). Tissue homogenates were centrifuged at 18,000 relative centrifugal force ( $\mathrm{rcf}$ ) for $30 \mathrm{~min}$. Equal amounts of protein for each sample were run on $4-12 \%$ Bis-Tris XT gels (Bio-Rad) and transferred to PVDF membranes. Blots were probed with the following antibodies: apoE (Academy Biomedical); APP (ZYMED); PS1-NTF (EMD Chemicals); $\beta$-secretase 1 (BACE1) (Cell Signaling Technology); synaptophysin (or SYP) (Sigma); glutamate receptor (GluR) 2/3/4 (Cell Signaling Technology); NMDAR2b (Cell Signaling Technology); postsynaptic density protein 95 (PSD-95) (Millipore); and tubulin (Sigma). Tubulinnormalized band intensity was quantified using NIH ImageJ software.

Sandwich ELISA for $A \beta$ and apoE. Cortical tissues were sequentially homogenized with PBS, modified RIPA, and $5 \mathrm{~m}$ guanidine $\mathrm{HCl}$ buffer. Tissue homogenates were centrifuged at 18,000 rcf for $30 \mathrm{~min}$ after each extraction. The levels of $A \beta$ and apoE were measured by enzyme-linked immunosorbent assay (ELISA). For A $\beta$ ELISA, HJ2 (anti-A $\beta 35-40$ ) and HJ7.4 (anti$\mathrm{A} \beta 37-42$ ) were used as capture antibodies, and HJ5.1-biotin (anti-A $\beta 13-$ $28)$ as the detection antibody. The anti-apoE monoclonal antibody WUE4 and another anti-apoE antibody (Calbiochem) were used for apoE ELISA.

Histology. Histology, staining, immunohistochemistry, and quantitative analysis were performed as described except that we used biotinylated mouse monoclonal antibody HJ3.4 (1:1000, targeted against amino acids $1-13$ of the human $A \beta$ sequence) to detect $A \beta$ in tissue sections (Kim et al., 2009b).

Statistical analysis. To determine the statistical significance $\left({ }^{*} p<\right.$ $\left.0.05,{ }^{* *} p<0.01,{ }^{* * *} p<0.001\right)$, we first tested whether our datasets passed the equal variance test (Levene Median test) and normality test
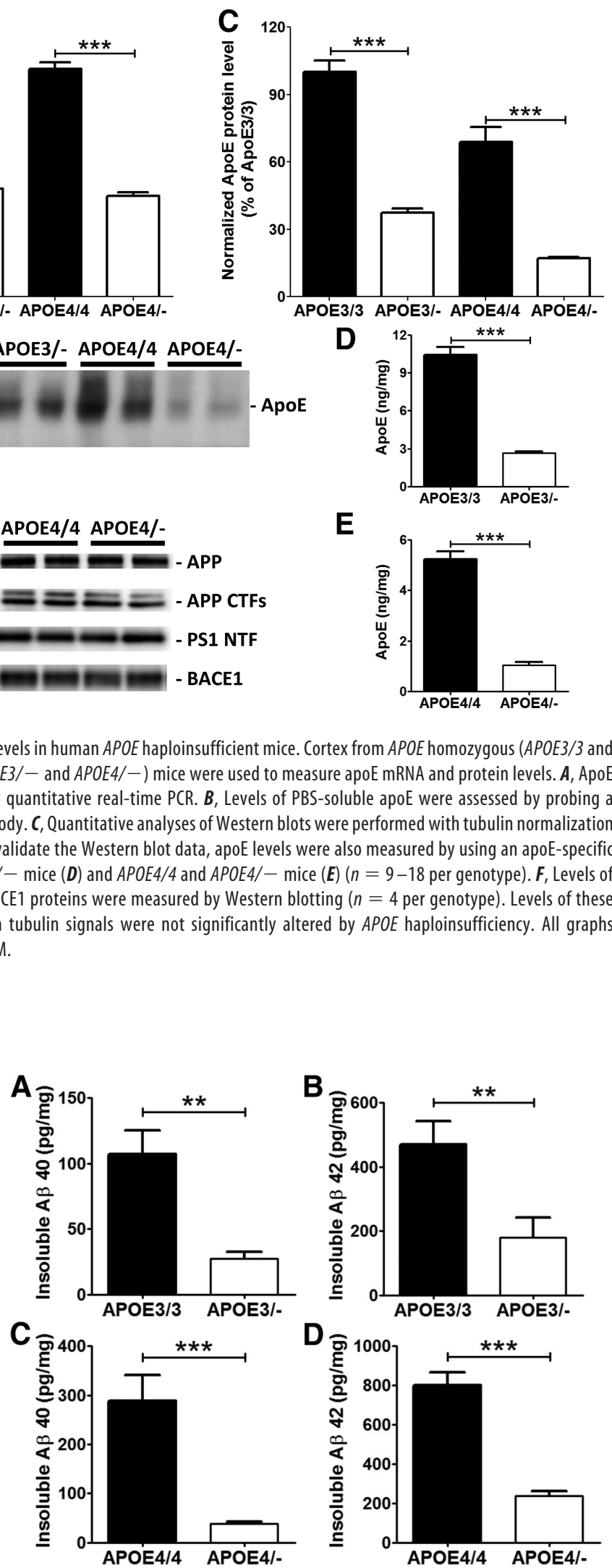

Figure 1. Reduction of apoE levels in human APOE haploinsufficient mice. Cortex from APOE homozygous ( $A P O E 3 / 3$ and $A P O E 4 / 4$ ) and hemizygous (APOE3/- and APOE4/-) mice were used to measure apoE mRNA and protein levels. $A, A p 0 E$

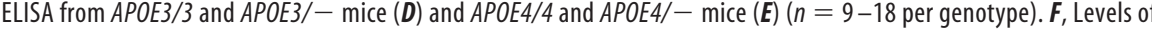
represent values in mean \pm SEM.

Figure 2. Decreased $A \beta$ accumulation in human $A P O E$ haploinsufficient mice. Cortical tissues from 3-month-old $A P O E$ homozygous and hemizygous mice were sequentially homogenized with PBS and RIPA. Aggregated forms of $A \beta$ in the RIPA-insoluble pellet were solubilized with 5 M guanidine $\mathrm{HCl}$ buffer. $\boldsymbol{A}, \boldsymbol{B}, \mathrm{RIPA}$-insoluble $A \beta 40(\boldsymbol{A})$ and $A \beta 42$ levels $(\boldsymbol{B})$ were measured from $A P O E 3 / 3$ and $A P O E 3 /-$ mice. $C$, $\boldsymbol{D}$, Similarly, RIPA-insoluble $A \beta 40(\boldsymbol{C})$ and $A \beta 42$ levels $(\boldsymbol{D})$ were measured from $A P O E 4 / 4$ and $A P O E 4 /-$ mice. $(n=12-20$ per genotype). 

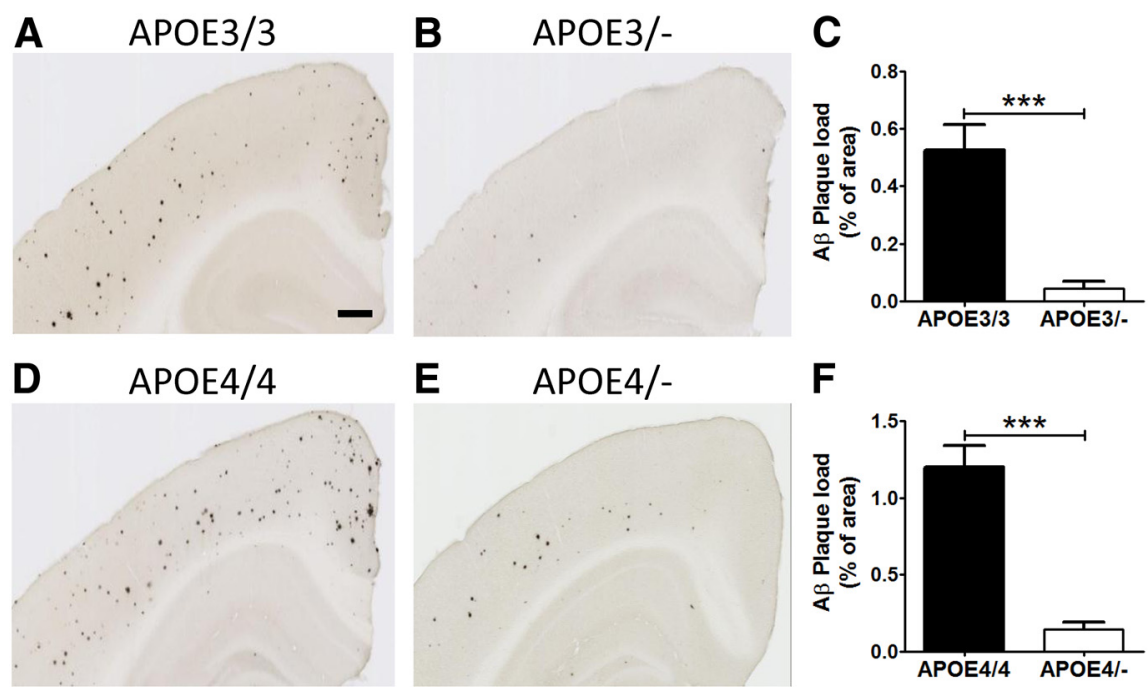

$\mathbf{F}$
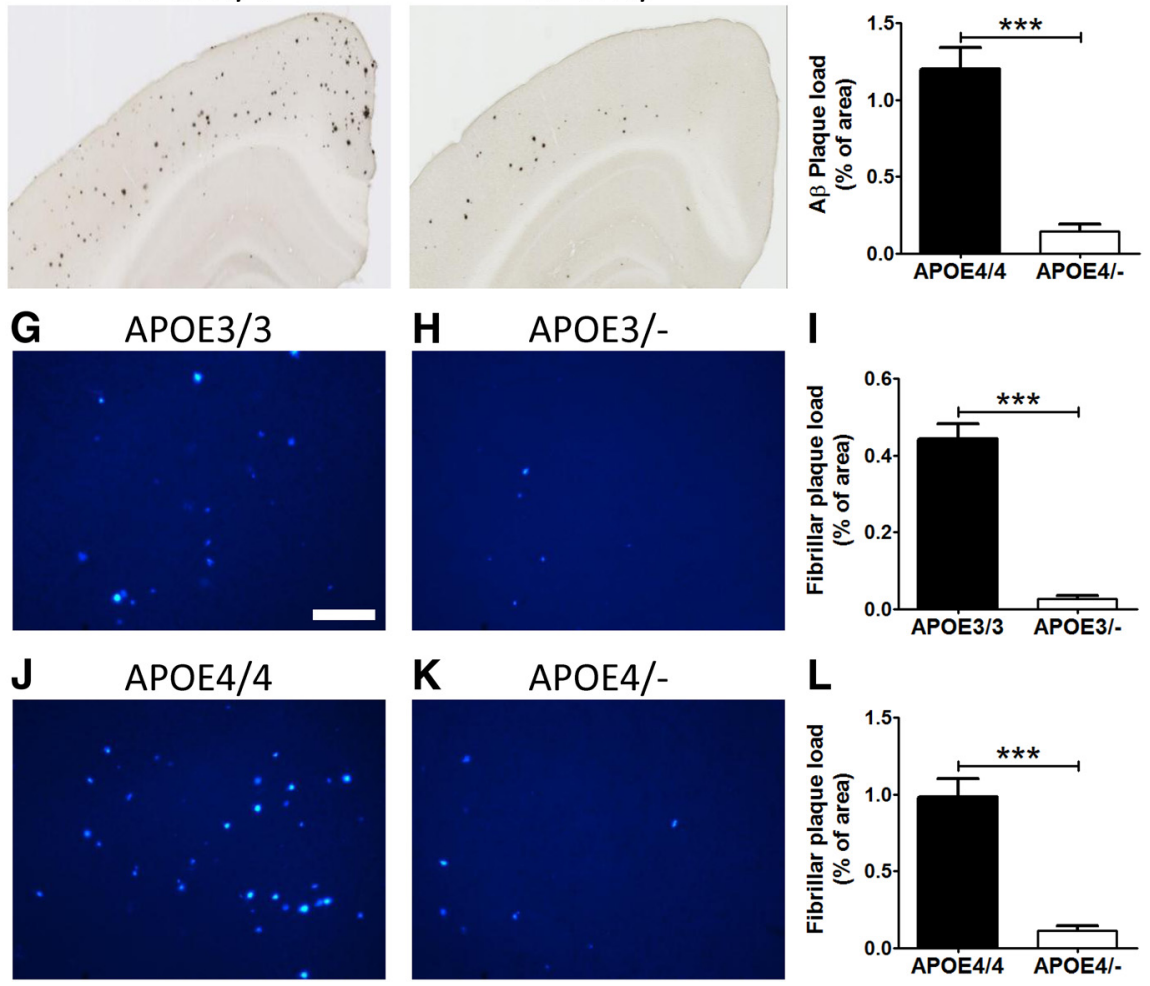

Figure 3. Haploinsufficiency of human $A P O E$ leads to reduction of $A \beta$ and fibrillar $A \beta$ plaque deposition. $\boldsymbol{A}, \boldsymbol{B}, \boldsymbol{D}, \boldsymbol{E}$, Brain sections from 3-month-old $A P O E$ homozygous $(\boldsymbol{A}, \boldsymbol{D})$ and hemizygous $(\boldsymbol{B}, \boldsymbol{E})$ mice were immunostained for amyloid with anti-A $\beta$ antibody (HJ3.4-biotin). Scale bars, $400 \mu \mathrm{m}$. $\boldsymbol{A}$-C, The extent of A $\beta$ deposition detected by HJ3.4-biotin antibody was quantified $(\boldsymbol{C})$ from cortex of $A P O E 3 / 3(\boldsymbol{A})$ and $A P O E 3 /-$ mice $(\boldsymbol{B})$. $\boldsymbol{D}-\boldsymbol{F}$, The extent of $A \beta$ deposition detected was quantified $(\boldsymbol{F})$ from cortex of $A P O E 4 / 4(\boldsymbol{D})$ and $A P O E 4 /$ - mice $(\boldsymbol{E}) . \boldsymbol{G}, \boldsymbol{H}, \boldsymbol{J}, \boldsymbol{K}$, Brain sections from 3-month-old APOE homozygous $(\boldsymbol{G}, \boldsymbol{J})$ and hemizygous $(\boldsymbol{H}$, K) mice were stained with X-34 dye that recognizes only fibrillar plaques. Scale bar, $200 \mu \mathrm{m}$. G-I, Fibrillar plaque load detected by X-34 dye was quantified $(\boldsymbol{I})$ from cortex of $A P O E 3 / 3$ homozygous $(\boldsymbol{G})$ and $A P O E 3 /-$ mice $(\boldsymbol{H})$. $\boldsymbol{J}-\boldsymbol{L}$, The extent of fibrillar plaque load was also analyzed $(\boldsymbol{L})$ from cortex of $A P O E 4 / 4(\boldsymbol{J})$ and $A P O E 4 /-$ mice $(\boldsymbol{E})$. ( $n=12-20$ per genotype).

(Kolmogorov-Smirnov test) (SigmaStat 3.5.). After confirmation that the data did not violate the assumptions of parametric testing, a twotailed Student's $t$ test was used (GraphPad Prism 5). Variance in all graphs represents SEM.

\section{Results}

Generation of human APOE haploinsufficient mouse models To directly examine the effect of decreasing human apoE levels on $\mathrm{A} \beta$ and amyloid deposition, we generated mouse models that have either one or two copies of the human APOE3 or APOE4 gene along with the APPswe/PS1(L166P) transgene (APPPS1-21 mice). $A P O E$ knock-in mouse models that express human apoE isoforms under the control of endogenous regulatory elements were used, eliminating any potentially confounding effects due to the presence of the endogenous murine Apoe gene.

First, we assessed the effect of $A P O E$ gene haploinsufficiency on apoE mRNA and protein levels in the cortex. As expected, apoE mRNA levels decreased by $\sim 50 \%$ in the hemizygous APOE3/- and
APOE4/- mice (Fig. 1A). Western blot analysis indicated that apoE protein levels were also significantly decreased in the $A P O E$ hemizygous compared with $A P O E$ homozygous mice (Fig. $1 B, C$ ). Consistent with the Western blot data, a similar decrease in apoE levels was observed by apoE ELISA for both APOE3 and APOE4 isoform mice (Fig. $1 D, E$ ). There were no significant alterations in the levels of proteins involved in $\mathrm{A} \beta$ production (Fig. $1 F$ ).

\section{Haploinsufficiency of human APOE dramatically inhibits $A \boldsymbol{\beta}$ accumulation To determine the effect of APOE geno- type and dosage on $\mathrm{A} \beta$, we analyzed $\mathrm{A} \beta$ accumulation in $A P O E$ homozygous and hemizygous mice. Significant re- ductions in insoluble $A \beta 40$ and $A \beta 42$ levels were observed in $A P O E 3 /-$ mice, compared with $A P O E 3 / 3$ mice (Fig. $2 A, B$ ). $A P O E 4 /-$ mice also had a dramatic de- crease in insoluble $A \beta 40$ and $A \beta 42$ levels compared with APOE4/E4 mice (Fig. $2 C, D)$. We also analyzed PBS-soluble $\mathrm{A} \beta$ levels in mice of all genotypes. Soluble $A \beta$ levels were $\sim 100$-fold less than PBS- insoluble $A \beta$ levels. PBS soluble $A \beta$ levels, except A $\beta 42$ levels between APOE4/4 and $A P O E 4 /-$ mice, were not altered by $A P O E$ haploinsufficiency (APOE3/3: A $\beta 40,5.82 \pm$ $0.31 \mathrm{pg} / \mathrm{mg} ; \mathrm{A} \beta 42,0.77 \pm 0.068 \mathrm{pg} / \mathrm{mg}$; APOE3/-: $\mathrm{A} \beta 40,5.27 \pm 0.32 \mathrm{pg} / \mathrm{mg} ; \mathrm{A} \beta 42$, $0.77 \pm 0.099 \mathrm{pg} / \mathrm{mg} ; A P O E 4 / 4: \mathrm{A} \beta 40$, $7.49 \pm 0.88 \mathrm{pg} / \mathrm{mg} ; \mathrm{A} \beta 42,1.39 \pm 0.13 \mathrm{pg} /$ mg; APOE4/-: A $\beta 40,7.90 \pm 0.51 \mathrm{pg} / \mathrm{mg}$; $\mathrm{A} \beta 42,1.12 \pm 0.058 \mathrm{pg} / \mathrm{mg})$.}

\section{Reduction of $\mathrm{A} \boldsymbol{\beta}$ and fibrillar $\mathrm{A} \boldsymbol{\beta}$ plaque load in human $A P O E$ hemizygous mice}

To determine the extent of $A \beta$ deposition in $A P O E$ homozygous and hemizygous mice, brain sections from 3-month-old mice were immunostained with a biotinylated anti-A $\beta$ antibody, HJ3.4 (Fig. 3A-F). Quantitative analyses of anti-A $\beta$ immunostaining demonstrated that $\mathrm{A} \beta$ plaque load was significantly decreased in $A P O E 3 /-$ mice compared with $A P O E 3 / 3$ mice (Fig. $3 C$ ). The level of $\mathrm{A} \beta$ deposition in both $A P O E 4 / 4$ and $A P O E 4 /-$ mice was also analyzed in the same way (Fig. $3 D, E$ ). While APOE $4^{+/+}$and $A P O E 4^{+/-}$mice had significantly greater $\mathrm{A} \beta$ deposition than $\mathrm{APOE}^{+/+}$and $\mathrm{APOE}^{+/-}$ mice respectively, $A P O E 4 /-$ mice had a dramatic reduction in $\mathrm{A} \beta$ plaque load, compared with $A P O E 4 / 4$ mice (Fig. $3 F$ ). To further characterize the nature of the deposited $A \beta$ plaques, brain sections were stained with X-34 dye that selectively detects only fibrillar, but not diffuse, $\mathrm{A} \beta$ deposits. Consistent with the anti-A $\beta$ antibody staining, $A P O E 3 /-$ and $A P O E 4 /-$ hemizygous mice had significantly less $\mathrm{X}$-34-positive fibrillar plaque load, compared with $A P O E 3 / 3$ and APOE4/4 homozygous mice (Fig. $3 G-L$ ). Together, our results clearly demonstrate that haploinsufficiency of $A P O E$ decreases both total $\mathrm{A} \beta$ and fibrillar amyloid deposition. 
APOE dosage-dependent modulation of neuroinflammatory response

Aberrant inflammatory responses, such as activation of microglia, are common pathological features in the brains of AD patients. To identify activated microglia in the brain, mouse brain sections were stained with anti-CD45 antibody, a marker of microgliosis. Plaque-associated microglial activation was evident around $\mathrm{A} \beta$ deposits in APPPS1-21 mice with $A P O E$ isoforms (Fig. 4A-D). Quantitative analysis of microgliosis indicated an $\sim 95 \%$ decrease in the CD45-positive activated microglial load in APOE3/- mice, compared with $A P O E 3 / 3$ littermates (Fig. $4 E$ ). A similar dramatic phenotype was observed between APOE4/4 and APOE4/- mice (Fig. $4 C, D)$. There was an $\sim 97 \%$ reduction in microgliosis in APOE4/- mice (Fig. 4F). These findings indicate that the reduction of $A \beta$ and amyloid formation by APOE haploinsufficiency is closely associated with an attenuation of the microglial neuroinflammatory response. We also analyzed the levels of presynaptic and postsynaptic proteins. Analysis of synaptophysin, GluR2/3/4, NMDA receptor 2b, and PSD-95 levels indicated there was no significant alteration in these proteins between genotypes or $A P O E$ dosage levels (Fig. 4G).

\section{Discussion}

We tested whether decreasing human apoE levels will increase or decrease $A \beta$ accumulation in vivo. Given the importance of this question, there have been numerous attempts to investigate the effects of modulating apoE levels on $\mathrm{AD}$ pathogenesis (Ashford, 2002; Rebeck et al., 2002; Teter et al., 2002). However, studies ranging from in vitro $\mathrm{A} \beta$ aggregation, ex vivo $\mathrm{A} \beta$ assays, and pharmacological approaches have provided conflicting results (Kim et al., 2009a). Most in vivo studies also provided limited information regarding the effect of human apoE modulation, since they indirectly inferred the effect of human apoE based on the manipulation of mouse apoE. To overcome some of the limitations of previous studies, we took a genetic approach by generating human APOE homozygous or hemizygous mice without the presence of the confounding endogenous mouse Apoe gene. A $\beta$-depositing mouse models with two copies $(A P O E 3 / 3$ or $A P O E 4 / 4)$ or one copy (APOE3/- or $A P O E 4 /-)$ of each $A P O E$ isoform were successfully generated. $A P O E 3 /-$ and $A P O E 4 /-$ mice had significantly less $A \beta$ accumulation, amyloid deposition, and microgliosis compared with the respective homozygous littermates. Thus, decreasing human apoE levels may be an attractive

E haploinsufficiency.
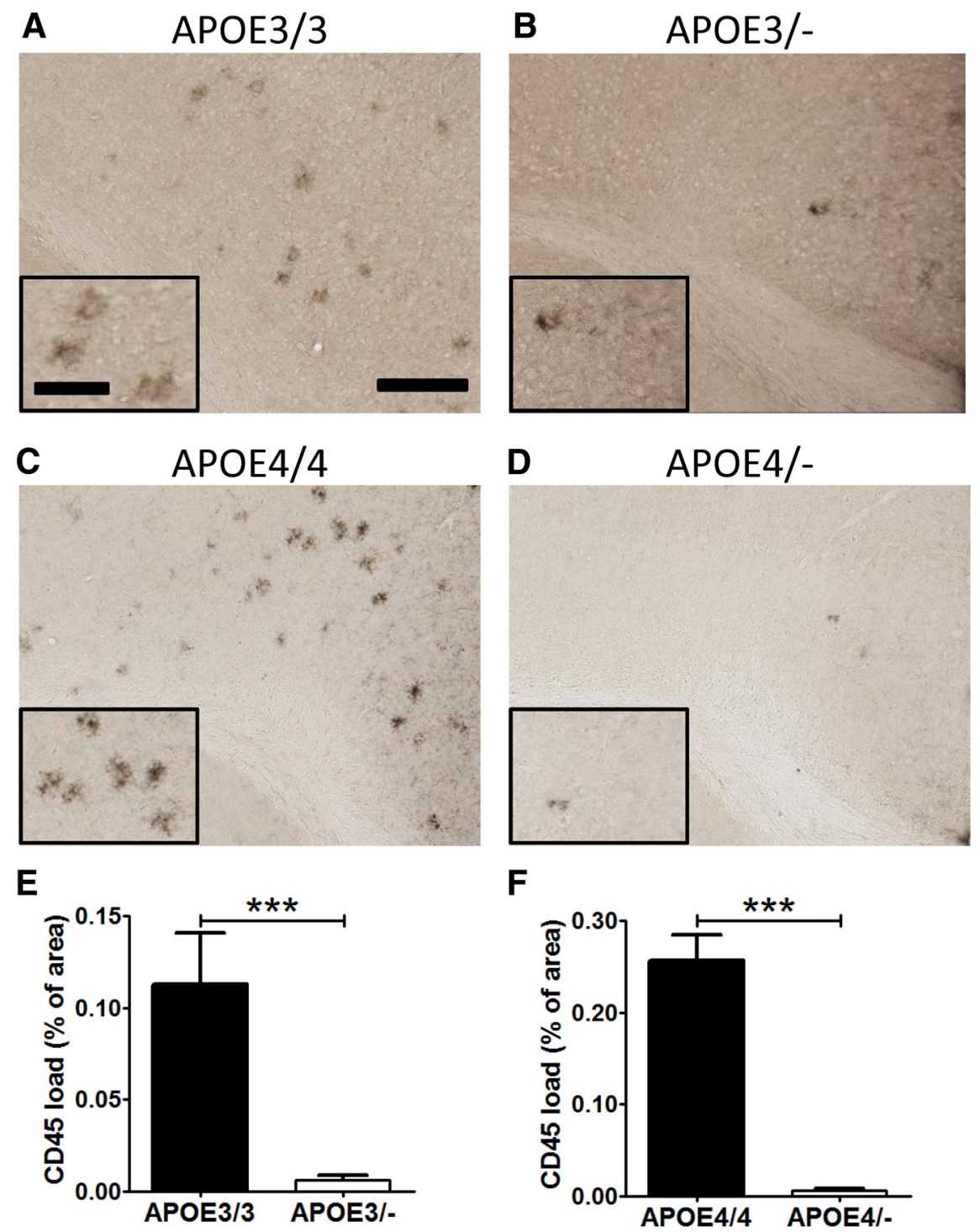

$\mathbf{F}$

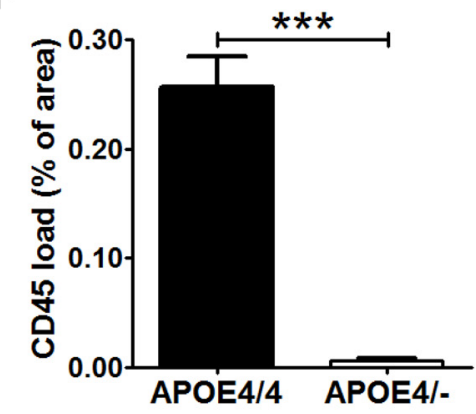

G APOE3/3 APOE3/- APOE4/4 APOE4/-
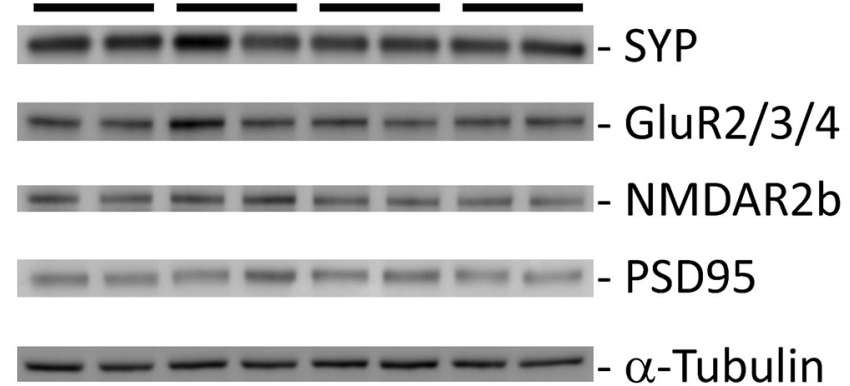

Figure 4. Attenuation of microgliosis in human $A P O E$ haploinsufficient mice. $\boldsymbol{A}-\boldsymbol{D}$, Brain sections from 3-month-old male $A P O E$ homozygous $(\boldsymbol{A}, \boldsymbol{C})$ and male hemizygous $(\boldsymbol{B}, \boldsymbol{D})$ mice were immunostained with an antibody against activated microglial CD45. $\boldsymbol{E}$, The percentage area covered by CD45 staining was quantified from the cortex of $A P O E 3 / 3$ and APOE3/- mice. $\boldsymbol{F}$, The extent of microgliosis was also quantified from the cortex of APOE4/4 and APOE4/- mice. Scale bars: lower magnification, $200 \mu \mathrm{m}$; higher magnification, $90 \mu \mathrm{m} . n=6-12$ male mice per genotype. $\mathbf{G}$, Levels of synaptophysin, GluR2/3/4, NMDA receptor 2b, and PSD-95 levels were measured by Western blotting $(n=4$ per genotype). Levels of these proteins after normalizing with tubulin signals were not significantly altered by APOE genotype or

therapeutic strategy for attenuating $\mathrm{A} \beta$ deposition and its downstream effects in $\mathrm{AD}$.

Given the critical role of $A \beta$ in $A D$ pathogenesis, the effect of apoE isoforms on $\mathrm{A} \beta$ deposition has been extensively investi- 
gated. APOE isoform-dependent amyloid deposition has been consistently observed in humans and $\mathrm{A} \beta$-depositing mouse models (Holtzman et al., 2000; Bales et al., 2009; Reiman et al., 2009; Morris et al., 2010). Consistent with previous studies with other APP mouse models, we also observed $A P O E$ isoformdependent effects on $\mathrm{A} \beta$ deposition in the APPPS1-21 mouse model (E4 > E3). Since apoE levels differ between APOE4/4 and $A P O E 3 / 3$, with levels of apoE4 being lower than apoE3, it is tempting to speculate that the difference in $A \beta$ accumulation between the apoE isoforms is due to differences in apoE3 versus apoE4 levels. However, the structures of apoE3 and apoE4 differ significantly from each other (Mahley et al., 2006), and the observed difference in $\mathrm{A} \beta$ deposition cannot be simply attributed to apoE4 levels being lower than apoE3. For example, APOE4/E4 mice have greater amyloid deposition than APOE3/- mice despite the fact that apoE4 levels are higher in the APOE4/E4 than in the APOE3/- mice. APOE gene dosage-dependent amyloid deposition could be due to an effect of an alteration in $\mathrm{A} \beta$ clearance and/or aggregation. Several studies demonstrated that apoE isoforms can differentially affect $\mathrm{A} \beta$ clearance (Deane et al., 2008; Jiang et al., 2008; Castellano et al., 2011). ApoE isoforms may be slowing $\mathrm{A} \beta$ clearance in an apoE-isoform-dependent manner $(\mathrm{E} 4>\mathrm{E} 3>\mathrm{E} 2)$. This idea is supported by the fact that mice lacking apoE have accelerated $\mathrm{A} \beta$ clearance from the brain relative to apoE-expressing mice (DeMattos et al., 2004). Another potentially important mechanism is direct facilitation of $A \beta$ fibrillogenesis by an ApoE and $\mathrm{A} \beta$ interaction. While there are a few conflicting reports (Kim et al., 2009a), several groups have reported that all three apoE isoforms increase $\mathrm{A} \beta$ fibrillogenesis, with the effect being most exacerbated with ApoE4 and the least with ApoE2 (Ma et al., 1994; Wisniewski et al., 1994; Castano et al., 1995).

Given the isoform-dependent effect on AD pathology, one therapeutic approach is to convert apoE4 to an apoE3-like protein by using a small molecule (Mahley et al., 2006). Disrupting the apoE- $\mathrm{A} \beta$ interaction could be another attractive therapeutic approach to prevent apoE-mediated $\mathrm{A} \beta$ aggregation (Sadowski et al., 2004). Previous studies suggested that modulation of apoE levels and lipidation state, independent of APOE genotype, may be another potential strategy to decrease $\mathrm{A} \beta$ accumulation (Cao et al., 2006; Wahrle et al., 2008; Kim et al., 2009b). Interestingly, deletion of ATP-binding cassette, subfamily A1 (Abcal) and liver $\mathrm{x}$ receptor $(L x r)$ genes decreased apoE levels but increased or had no effect on A $\beta$ deposition (Hirsch-Reinshagen et al., 2005; Koldamova et al., 2005; Wahrle et al., 2005; Zelcer et al., 2007). In addition, several studies have shown that activation of $L x r$ increases mouse apoE and decreases $\mathrm{A} \beta$ levels (Jiang et al., 2008). However, it is difficult to interpret the effect of altering apoE level in these studies, since modulation of Abcal and Lxr also influences the lipidation state of apoE. Whether reducing human apoE levels without affecting its lipidation state will promote or attenuate $\mathrm{A} \beta$ accumulation was not clear from previous studies. Our study demonstrates the beneficial effect of decreasing apoE levels on $A \beta$ accumulation. Consistent with our finding, low levels of apoE were strongly associated with low cerebral $A \beta$ load in humans (Darreh-Shori et al., 2011). APOE gene promoter studies also suggest that higher levels of apoE, regardless of isoform status, increase the risk of developing $\mathrm{AD}$ (Laws et al., 2003). APOE may also influence risk for $\mathrm{AD}$ by mechanisms that are not related to $A \beta$. We found no clear differences in presynaptic and postsynaptic proteins in APPPS1-21 mice of different APOE genotypes and doses. This, however, does not rule out the possibility the structural synaptic changes might be present that have been ob- served by others (Dumanis et al., 2009). Our results in which apoE levels are altered by changing gene dosage suggest that strategies to decrease apoE levels in the brain should be further explored for the prevention/treatment of AD. Changing apoE levels in an adult in the context of two copies of $A P O E$ is different than having a lifelong genetic alteration of $A P O E$ dosage as in our experiments. It will be important to see in the former context whether altering apoE levels in an adult with two endogenous copies of APOE has similar or different effects as we report herein.

\section{References}

Ashford JW (2002) ApoE4: is it the absence of good or the presence of bad? J Alzheimers Dis 4:141-143.

Bales KR, Verina T, Dodel RC, Du Y, Altstiel L, Bender M, Hyslop P, Johnstone EM, Little SP, Cummins DJ, Piccardo P, Ghetti B, Paul SM (1997) Lack of apolipoprotein E dramatically reduces amyloid beta-peptide deposition. Nat Genet 17:263-264.

Bales KR, Liu F, Wu S, Lin S, Koger D, DeLong C, Hansen JC, Sullivan PM, Paul SM (2009) Human APOE isoform-dependent effects on brain $\beta$-amyloid levels in PDAPP transgenic mice. J Neurosci 29:6771-6779.

Cao D, Fukuchi K, Wan H, Kim H, Li L (2006) Lack of LDL receptor aggravates learning deficits and amyloid deposits in Alzheimer transgenic mice. Neurobiol Aging 27:1632-1643.

Castano EM, Prelli F, Wisniewski T, Golabek A, Kumar RA, Soto C, Frangione B (1995) Fibrillogenesis in Alzheimer's disease of amyloid beta peptides and apolipoprotein E. Biochem J 306:599-604.

Castellano JM, Kim J, Stewart FR, Jiang H, DeMattos RB, Patterson BW, Fagan AM, Morris JC, Mawuenyega KG, Cruchaga C, Goate AM, Bales KR, Paul SM, Bateman RJ, Holtzman DM (2011) Human apoE isoforms differentially regulate brain amyloid- $\beta$ peptide clearance. Sci Transl Med 3:89ra57.

Darreh-Shori T, Forsberg A, Modiri N, Andreasen N, Blennow K, Kamil C, Ahmed H, Almkvist O, Langstrom B, Nordberg A (2011) Differential levels of apolipoprotein $\mathrm{E}$ and butyrylcholinesterase show strong association with pathological signs of Alzheimer's disease in the brain in vivo. Neurobiol Aging 32:2320.e15-32.

Deane R, Sagare A, Hamm K, Parisi M, Lane S, Finn MB, Holtzman DM, Zlokovic BV (2008) apoE isoform-specific disruption of amyloid beta peptide clearance from mouse brain. J Clin Invest 118:4002-4013.

DeMattos RB, Cirrito JR, Parsadanian M, May PC, O’Dell MA, Taylor JW, Harmony JA, Aronow BJ, Bales KR, Paul SM, Holtzman DM (2004) ApoE and clusterin cooperatively suppress Abeta levels and deposition: evidence that ApoE regulates extracellular Abeta metabolism in vivo. Neuron 41:193-202.

Dumanis SB, Tesoriero JA, Babus LW, Nguyen MT, Trotter JH, Ladu MJ, Weeber EJ, Turner RS, Xu B, Rebeck GW, Hoe HS (2009) ApoE4 decreases spine density and dendritic complexity in cortical neurons in vivo. J Neurosci 29:15317-15322.

Hirsch-Reinshagen V, Maia LF, Burgess BL, Blain JF, Naus KE, McIsaac SA, Parkinson PF, Chan JY, Tansley GH, Hayden MR, Poirier J, Van Nostrand W, Wellington CL (2005) The absence of ABCA1 decreases soluble ApoE levels but does not diminish amyloid deposition in two murine models of Alzheimer disease. J Biol Chem 280:43243-43256.

Holtzman DM, Bales KR, Tenkova T, Fagan AM, Parsadanian M, Sartorius LJ, Mackey B, Olney J, McKeel D, Wozniak D, Paul SM (2000) Apolipoprotein $\mathrm{E}$ isoform-dependent amyloid deposition and neuritic degeneration in a mouse model of Alzheimer's disease. Proc Natl Acad Sci U S A 97:2892-2897.

Holtzman DM, Morris JC, Goate AM (2011) Alzheimer's disease: the challenge of the second century. Sci Transl Med 3:77sr1.

Jiang Q, Lee CY, Mandrekar S, Wilkinson B, Cramer P, Zelcer N, Mann K, Lamb B, Willson TM, Collins JL, Richardson JC, Smith JD, Comery TA, Riddell D, Holtzman DM, Tontonoz P, Landreth GE (2008) ApoE promotes the proteolytic degradation of Abeta. Neuron 58:681-693.

Kim J, Basak JM, Holtzman DM (2009a) The role of apolipoprotein E in Alzheimer's disease. Neuron 63:287-303.

Kim J, Castellano JM, Jiang H, Basak JM, Parsadanian M, Pham V, Mason SM, Paul SM, Holtzman DM (2009b) Overexpression of low-density lipoprotein receptor in the brain markedly inhibits amyloid deposition and increases extracellular A[beta] clearance. Neuron 64:632-644.

Koldamova R, Staufenbiel M, Lefterov I (2005) Lack of ABCA1 consider- 
ably decreases brain ApoE level and increases amyloid deposition in APP23 mice. J Biol Chem 280:43224-43235.

Laws SM, Hone E, Gandy S, Martins RN (2003) Expanding the association between the APOE gene and the risk of Alzheimer's disease: possible roles for APOE promoter polymorphisms and alterations in APOE transcription. J Neurochem 84:1215-1236.

Ma J, Yee A, Brewer HB Jr, Das S, Potter H (1994) Amyloid-associated proteins alpha 1-antichymotrypsin and apolipoprotein E promote assembly of Alzheimer beta-protein into filaments. Nature 372:92-94.

Mahley RW, Weisgraber KH, Huang Y (2006) Apolipoprotein E4: A causative factor and therapeutic target in neuropathology, including Alzheimer's disease. Proc Natl Acad Sci U S A 103:5644-5651.

Morris JC, Roe CM, Xiong C, Fagan AM, Goate AM, Holtzman DM, Mintun MA (2010) APOE predicts amyloid-beta but not tau Alzheimer pathology in cognitively normal aging. Ann Neurol 67:122-131.

Osherovich L (2009) The APOE4 conundrum. SciBX 2:1-3.

Radde R, Bolmont T, Kaeser SA, Coomaraswamy J, Lindau D, Stoltze L, Calhoun ME, Jäggi F, Wolburg H, Gengler S, Haass C, Ghetti B, Czech C, Hölscher C, Mathews PM, Jucker M (2006) Abeta42-driven cerebral amyloidosis in transgenic mice reveals early and robust pathology. EMBO Rep 7:940-946.

Rebeck GW, Kindy M, LaDu MJ (2002) Apolipoprotein E and Alzheimer's disease: the protective effects of ApoE2 and E3. J Alzheimers Dis $4: 145-154$.

Reiman EM, Chen K, Liu X, Bandy D, Yu M, Lee W, Ayutyanont N, Keppler J, Reeder SA, Langbaum JB, Alexander GE, Klunk WE, Mathis CA, Price JC, Aizenstein HJ, DeKosky ST, Caselli RJ (2009) Fibrillar amyloid-beta burden in cognitively normal people at 3 levels of genetic risk for Alzheimer's disease. Proc Natl Acad Sci U S A 106:6820-6825.

Sadowski M, Pankiewicz J, Scholtzova H, Ripellino JA, Li Y, Schmidt SD, Mathews PM, Fryer JD, Holtzman DM, Sigurdsson EM, Wisniewski T
(2004) A synthetic peptide blocking the apolipoprotein E/beta-amyloid binding mitigates beta-amyloid toxicity and fibril formation in vitro and reduces beta-amyloid plaques in transgenic mice. Am J Pathol 165: 937-948.

Strittmatter WJ, Saunders AM, Schmechel D, Pericak-Vance M, Enghild J, Salvesen GS, Roses AD (1993) Apolipoprotein E: high-avidity binding to beta-amyloid and increased frequency of type 4 allele in late-onset familial Alzheimer disease. Proc Natl Acad Sci U S A 90:1977-1981.

Sullivan PM, Mezdour H, Aratani Y, Knouff C, Najib J, Reddick RL, Quarfordt SH, Maeda N (1997) Targeted replacement of the mouse apolipoprotein $\mathrm{E}$ gene with the common human APOE3 allele enhances dietinduced hypercholesterolemia and atherosclerosis. J Biol Chem 272: 17972-17980.

Teter B, Raber J, Nathan B, Crutcher KA (2002) The presence of apoE4, not the absence of apoE3, contributes to AD pathology. J Alzheimers Dis 4:155-163.

Wahrle SE, Jiang H, Parsadanian M, Hartman RE, Bales KR, Paul SM, Holtzman DM (2005) Deletion of Abcal increases Abeta deposition in the PDAPP transgenic mouse model of Alzheimer disease. J Biol Chem 280:43236-43242.

Wahrle SE, Jiang H, Parsadanian M, Kim J, Li A, Knoten A, Jain S, HirschReinshagen V, Wellington CL, Bales KR, Paul SM, Holtzman DM (2008) Overexpression of ABCA1 reduces amyloid deposition in the PDAPP mouse model of Alzheimer disease. J Clin Invest 118:671-682.

Wisniewski T, Castaño EM, Golabek A, Vogel T, Frangione B (1994) Acceleration of Alzheimer's fibril formation by apolipoprotein $\mathrm{E}$ in vitro. Am J Pathol 145:1030-1035.

Zelcer N, Khanlou N, Clare R, Jiang Q, Reed-Geaghan EG, Landreth GE, Vinters HV, Tontonoz P (2007) Attenuation of neuroinflammation and Alzheimer's disease pathology by liver x receptors. Proc Natl Acad Sci U S A 104:10601-10606. 